\title{
PENYELESAIAN SENGKETA PERTANAHAN DI WILAYAH MADURA SECARA MEDIASI OLEH BADAN PERTANAHAN NASIONAL
}

\author{
Hamidi $^{1}$, Moh Abdul Latif ${ }^{2}$ \\ STAI Al-Hamidiyah Bangkalan ${ }^{1}$, IAIN Kudus ${ }^{2}$ \\ Email : hamidiarrohmany@gmail.com, Email : abdullathif@iainkudus.ac.id
}

\begin{abstract}
The land issue in Madura is a very complicated issue, especially regarding private interests, the general public, and legal entities. This research explains the mechanism for resolving land disputes in the Madura region through mediation by the National Land Agency, and the mediator's method of resolving land disputes. This study uses an empirical juridical research method, which in this study examines the applicable legal provisions and what happens in reality in society. The results showed that the mediation mechanism carried out by the National Land Agency included first receiving a letter of complaint from one of the parties, secondly reviewing the complaint letter, thirdly calling the Camat, Village Head, Village Apparatus, and Community Leaders for questioning regarding land disputes. The mediator's way of resolving land cases in the Madura region through mediation is, First Calling the two disputing parties, second Mediation efforts are carried out on both parties to the dispute, third If the mediation is successful then a mediation report and a letter of peace agreement are made and if it is not successful then the mediator directs to resolve through the path of legitimacy.
\end{abstract}

Keywords: Settlement, Land Dispute, Mediation

\begin{abstract}
Abstrak
Masalah tanah di Madura merupakan masalah yang sangat rumit, terutama mengenai kepentingan pribadi, masyarakat umum, maupun badan hukum. Peneletian ini bertujuan menjelaskan mekanisme penyelesaian sengketa pertanahan di wilayah Madura secara mediasi oleh Badan Pertanahan Nasional, dan cara mediator dalam menyelesaikan sengketa pertanahan. Penelitian ini menggunakan metode penelitian yuridis empiris, dimana dalam penelitian ini mengkaji ketentuan hukum yang berlaku serta apa yang terjadi dalam kenyataannya di masyarakat. Hasil penelitian menunjukkan bahwa mekanisme mediasi yang dilakukan oleh Badan Pertanahan Nasional diantaranya adalah pertama menerima surat pengaduan dari salah satu pihak, kedua Menelaah surat pengaduan, ketiga Memanggil Camat, Kepala Desa, Perangkat Desa, dan Tokoh Masyarakat untuk dimintai keterangannya mengenai sengketa pertanahan. Adapun cara mediator dalam menyelesaikan kasus pertanahan di wilayah Madura secara mediasi adalah, pertama Memanggil kedua belah pihak yang bersengketa, kedua upaya mediasi dilakukan terhadap kedua belah pihak yang bersengketa, ketiga apabila mediasi berhasil maka dibuatlah berita acara mediasi
\end{abstract}


dan surat perjanjian perdamaian dan apabila tidak berhasil maka mediator mengarahkan untuk menyelesaikan di lewat jalur letigasi.

Kata Kunci: Penyelesaian, Sengketa Pertanahan, Mediasi

\section{PENDAHULUAN}

Tanah merupakan kebutuhan pokok (primer) bagi manusia untuk melangsungkan hidup dan kehidupannya, tanpa tanah seseorang tidak dapat melakukan hak-hak hidupnya secara normal dan aman seperti orang lain yang mempunyai tanah (Nurus Zaman, 2016: 4). Di samping itu manusia sebagai makhluk sosial (zoon politicon) masih membutuhkan bantuan orang lain untuk mengurus atau menyelesaikan sengketa tanah yang dihadipinya. Semua orang tentu tidak ingin bersengketa dengan orang lain dan berkeinginan hidup dengan damai dan saling menghormati. Namun dalam kehidupan masyarakat yang sangat kompleks, baik secara etnik, ekonomi, sosial, budaya dan ragam keinginan yang berbeda dari setiap orang, sengketa sulit untuk dihindarkan.

Sengketa pertanahan dapat terjadi antara kedua belah pihak secara individual, komunal bahkan banyak melibatkan banyak pihak dan Negara, dari sengketa yang sederhana sampai yang paling krusial (Candra Irawan, 2010: 1). Faktor-faktor terjadinya sebuah sengketa terhadap tanah karena adanya pengaduan dari salah satu pihak (Orang atau Badan Hukum) yang berisi keberatan-keberatan dan tuntutan hak atas tanah prioritas maupun kepemilikannya dengan harapan akan memperoleh penyelesaian secara adil tanpa adanya keberpihakan.

Sengketa pertanahan merupakan permasalahan yang mendasar dan sudah banyak terjadi di semua daerah khususnya pada masyarakat Madura, satu permasalah belum selesai telah muncul permasalahan lagi. Hal ini dimungkinkan karena belum diperoleh cara yang tepat untuk menyelesaikannya. Hal itu sudah pernah terjadi di Dusun Labuhan, Desa Labuhan, Kecamatan Sreseh, Kabupaten Sampang dan sampai sekarang belum menemukan solusi yang baik bagi para pihak yang bersengketa, meskipun sudah dilakukan mediasi oleh Kepala Desa, dan Camat, sehingga keberadaan tanah tersebut sampai sekarang dinamakan tanah sengketa.

Badan Pertanahan di wilayah Madura yakni, Sampang, Bangkalan, Pamekasan dan Sumenep sebagai pelaksana kewenangan untuk menyelesaikan kasus sengketa pertanahan sekaligus sebagai mediator dalam mediasi belum dapat melaksanakan kewenangannya sehingga masih banyak sengketa tanah yang masih dibawa ke pengadilan. Meskipun sudah ditentukan dalam Peraturan Menteri Agraria dan Tata Ruang/Kepala Badan Pertanahan Nasional Republik 
Indonesia Nomor 11 Tahun 2016 Tentang Penyelesaian Kasus Pertanahan.

Secara historis dan kultural, masyarakat Madura terutama di pedesaan telah terbiasa menggunakan cara-cara lokal atau di luar pengadilan dalam menyelesaikan perselisihan. Menurut mereka merupakan hal yang sangat memalukan apabila permasalahan sengketa tanah dibawa ke pengadilan, salah satu cara yang digunakan dalam menyelesaikan sengketa tanah adalah mediasi hal ini disebabkan karena mediasi adalah cara yang paling mudah dan cepat dalam menyelesaikan perselisihan. Upaya penyelesaian sengketa diluar peradilan merupakan hal yang lazim digunakan dalam penyelesaian sengketa keperdataan sebagai jalan keluar melalui non litigasi atau damai serta musyawarah mufakat. Cara penyelesaian demikian diperbolehkan karena tujuan Hukum Perdata adalah untuk melindungi hak-hak privat. Mediasi merupakan salah satu cara dalam penyelesaian sengketa selain negosiasi, arbitrase dan pengadilan (Maria S. Sumardjono, 2008: 23).

Masyarakat Madura sebenarnya masih tergolong dalam wilayah Hukum Adat, dimana Hukum Adat juga merupakan perwujudan nilainilai masyarakat yang mengakomodasi kepentingan masyarakat dan memperhatikan kepentingan individu termasuk pihak-pihak yang bersengketa. Pasal 18B ayat (2) Undang-Undang Dasar Negara Republik Indonesia Tahun 1945, menyatakan bahwa "Negara mengakui dan menghormati kesatuan-kesatuan masyarakat Hukum Adat beserta hakhak tradisionalnya sepanjang masih hidup dan sesuai dengan perkembangan masyarakat dan prinsip Negara Kesatuan Republik Indonesia yang diatur dalam undang-undang". Artinya, keberadaan Hukum Adat juga diakui oleh Negara dan termaktub dalam UndangUndang Dasar Negara Republik Indonesia. Penyelesaian sengketa pertanahan terhadap masyarakat madura melalui cara mediasi dimaksudkan untuk mencapai kemajemukan hukum dengan catatan bahwa pengakuan dan pengadopsian hukum tidak hanya ditempuh melalui peraturan perundang-undangan, tetapi juga melalui yurisprudensi (Maria S. Sumardjono, 2008: 57).

Pada dasarnya penyelesaian sengketa dapat dilakukan melalui 2 (dua) jalur yaitu, jalur Peradilan (Litigasi) dan jalur di luar Peradilan (Non litigasi). Pasal 1 angka 10 Undang-Undang Nomor 30 Tahun 1999 tentang Arbritase dan Alternatif Penyelesaian Sengketa menyatakan bahwa alternatif penyelesaian sengketa adalah lembaga penyelesaian sengketa melalui prosedur yang disepakati para pihak yakni penyelesaian di luar pengadilan dengan cara konsultasi, negosiasi, mediasi, konsoliasi atau penilaian ahli. Meskipun penyelesaian melalui jalur di luar pengadilan keberadaannya sudah diakui, namun tidak jarang masih menimbulkan ketidakpuasan bagi para pihak yang bersengketa karena dalam proses 
pengambilan keputusan terdapat kontradiksi aturan dan disisi lain peran pengadilan masih dominan dalam menyelesaikan sengketa. Di samping itu belum ada penjelasan spesifik tentang cara penyelesaian sengketa melalui jalur mediasi bagi para pihak yang mempunyai kepentingan.

Penyelesaian sengketa pertanahan dengan cara mediasi dapat diselesaikan melalui lembaga-lemabaga di luar pengadilan, salah satunya yaitu melalui Badan Pertanahan Nasional (selanjutnya disebut BPN). Dengan diundangkannya Undang-Undang Nomor 5 Tahun 1960 tentang Peraturan Dasar Pokok-Pokok Agraria yang di undangkan pada tanggal 24 September 1960 yang dikenal dengan istilah UUPA, merupakan pelaksanaan Pasal 33 ayat (3) Undang-Undang Dasar Negara Republik Indonesia Tahun 1945, menyatakan "Bahwa bumi dan air dan kekayaan alam yang terkandung di dalamnya dikuasai oleh Negara dan dipergunakan untuk sebesar-besarnya kemakmuran rakyat".

Berlakunya Undang-Undang Pokok Agraria (selanjutnya disebut UUPA), maka untuk pertama kalinya Indonesia mempunyai suatu lembaga pendaftaran tanah dalam sejarah pertanahan di Indonesia, yang berlaku secara nasional. sebagai konsekuensi berlakunya Peraturan Pemerintah Nomor 10 Tahun 1961 yang kemudian disempurnakan dengan Peraturan Pemerintah Nomor 24 Tahun 1997 sebagai perintah dari Pasal 19 ayat (1) UUPA yang menyatakan "Untuk menjamin kepastian hukum, oleh pemerintah diadakan pendaftaran tanah diseluruh wilayah Republik Indonesia menurut ketentuan-ketentuan yang diatur oleh peraturan pemerintah".

Berdasarkan Peraturan Menteri Agraria dan Tata Ruang/Kepala Badan Pertanahan Nasional Republik Indonesia Nomor 11 Tahun 2016 tentang Penyelesaian Kasus Pertanahan menyatakan bahwa Badan Pertanahan Nasional mempunyai kewenangan untuk menyelesaikan sengketa pertanahan yang berada di wilayah hukumnya melalui cara Mediasi. Meskipun Badan Pertanahan Nasional sudah mempunyai kewenangan dengan keluarnya Peraturan Menteri Agraria dan Tata Ruang/Kepala Badan Pertanahan Nasional Republik Indonesia Nomor 11 Tahun 2016 tentang Penyelesaian Kasus Pertanahan. Namun isu hukum yang berkembang dalam masyarakat Madura mengenai mekanisme mediasi dalam penyelesaian sengketa tanah oleh Badan Pertanahan Nasional belum memberikan kepuasan bagi para pihak yang bersengketa dan cara mediator dalam menyelesaikan sengketa tanah di Badan Pertanahan Nasional masih menimbulkan keluhan masyarakat Madura, sehingga permasalahan tanah sampai saat ini semakin kompleks terutama menyangkut hak milik atas tanah.

Penelitian yang mengkaji tentang penyelesaian sengketa pertanahan pada dasarnya sudah banyak dilakukan baik dalam bentuk penelitian normatif maupun empiris. Seperti penelitian yang dilakukan oleh Herwandi (2010) dengan judul “Peran Kantor Pertanahan Dalam 
Rangka Penyelesaian Sengketa Tanah Secara Mediasi di Kantor Pertanahan Jakarta Utara". Hasil kajiannya menunjukkan bahwa kantor Pertanahan Jakarta Utara sebagai mediator mempunyai peran untuk membantu para pihak dalam memahami pandangan masing-masing dan membantu mencari hal-hal yang dianggap penting bagi mereka dalam menyelesaikan sengketa tanah.

Pratama (2016) dengan Judul penelitiannya "Penyelesaian Sengketa Dengan Mediasi Melalui Badan Pertanahan Nasional Antara PT. Meri dan Sejati Surya Plantation Dengan Kelompok Tani Tunas Jaya di Kabupaten Siak Provinsi Riau". Hasil penelitiannya menunjukkan di antaranya yaitu PT. Mari menyatakan bahwa tanah HGU yang mereka miliki telah diperoleh dengan sah dan telah dilakukan pembayaran ganti rugi terhadap tanah masyarakat yang berada dalam lokasi HGU yang dikeluarkan oleh pejabat yang berwenang (SKT yang dikeluarkan oleh desa), dan Kelompok Tani Tunas Jaya tidak bisa menunjukkan secara konkrit lahan yang mereka bahwa lahan itu adalah milik mereka.

Seperti yang telah disinggung di atas bahwa persamaan antara penelitian sebelumnya dengan penelitian ini adalah sama-sama mengkaji berhubungan dengan penyelesaian sengketa pertenahan, adapun perbedaanya adalah terletak permasalahan yang menjadi obyek kajian. Kajian penelitian ini lebih menfokuskan permasalahan mengenai mekanisme penyelesaian sengketa pertanahan di wilayah Madura secara mediasi oleh Badan Pertanahan Nasional, dan cara mediator dalam menyelesaikan sengketa pertanahan. Sehingga penelitian ini bertujuan menjelaskan tentang mekanisme penyelesaian sengketa pertanahan di wilayah Madura secara mediasi oleh Badan Pertanahan Nasional, dan cara mediator dalam menyelesaikan sengketa pertanahan.

\section{METODE PENELITIAN}

Penelitian ini termasuk dalam kategori jenis penelitian yuridis empiris atau yuridis sosiologis yaitu penelitian yang mengkaji hukum yang berlaku serta apa yang terjadi dalam kenyataan di masyarakat (B. Waluyo, 2002: 16). Adapun pendekatan yang digunakan penelitian ini adalah kualitatif berupa studi kasus. Pendekatan tersebut dimaksudkan untuk mengetahui mekanisme penyelesaian sengketa pertanahan di wilayah Madura secara mediasi oleh Badan Pertanahan Nasional, dan cara mediator dalam menyelesaikan sengketa pertanahan. Sumber data dalam penelitian ini adalah menggunakan data primer dan data sekunder. Data primer berupa wawancara bebas terpimpin. Data sekunder berupa mencakup bahan hukum primer, bahan hukum sekunder, dan bahan hukum tersier.

Bahan hukum primer berupa peratuan perundang-undangan mengenai pertanahan yaitu Undang-Undang Nomor 5 Tahun 1960 
tentang Peraturan Dasar Pokok-Pokok Agraria, Peraturan Menteri Agraria dan Tata Ruang/Kepala Badan Pertanahan Nasional Republik Indonesia Nomor 11 Tahun 2016 Tentang Penyelesaian Kasus Pertanahan, dan Undang-Undang Nomor 30 Tahun 1999 tentang Arbritase dan Alternatif Penyelesaian Sengketa. Bahan hukum sekunder berupa buku-buku pertanahan, artikel ilmiah, majalah dan lain-lain. Bahan hukum tersier berupa kamus hukum, ensiklopedi dan lain sebagainya.

Teknik pengumpulan data berupa observasi dan wawancara. sementara itu, untuk uji keabsahan data penelitian ini menggunakan triangulasi teknik, sumber, dan waktu. Selanjutnya, data yang diperoleh dilakukan analisis data menggunakan metode kualitatif bersifat diskriptif. penggunaan metode kualitiatif bersifat diskriptif ini bertujuan untuk mendiskripsikan mengenai mekanisme penyelesaian sengketan pertanahan di wilayah Madura dengan cara mediasi oleh Badan Pertanahan Nasional.

\section{PEMBAHASAN}

Persoalan yang menyangkut sengketa dibidang pertanahan, khususnya yang terjadi di wilayah Madura dapat dikatakan tidak pernah surut, bahkan mempunyai kecenderungan meningkat dalam kompleksitas permasalahannya, maupun kuantitasnya seiring dinamika dibidang ekonomi, sosial, politik dan budaya. Masyarakat Madura merupakan masyarakat komunal dan relegius dalam berperilaku, mereka tidak akan berbuat salah dan membuat suatu masalah terhadap orang lain apalagi terhadap keluarga juga lingkungan disekitarnya. Mereka lebih memilih bekerja untuk menafkahi keluarganya, namun ketika ada seseorang yang mencoba merebut hak-haknya mereka rela berkorban untuk memperjuangkan sampai titik darah penghabisan, termasuk tanah yang dimilikinya.

Masyarakat Madura juga beranggapan bahwa tanah yang ia miliki merupakan pemberian dari Allah SWT, di samping itu merupakan kebutuhan primer. Ciri khas masyarakat Madura memang beda dari masyarakat lain, ketika ada suatu permasalahan apapun termasuk sengketa tanah ia lebih memilih cara penyelesaian di luar pengadilan (Non litigasi) yaitu melalui mediasi/musyawarah dan mufakat.

Menurut Asmawati, Mediasi adalah suatu proses penyelesaian sengketa antara dua pihak atau lebih melalui perundingan atau cara mufakat dengan bantuan pihak ketiga yang netral dan tidak memiliki kewenangan memutus. Pihak ketiga tersesebut disebut mediator dengan tugas memberikan bantuan prosedural dan substansial. Sehingga unsurunsur esensial mediasi yaitu (Asmawati, 1999):

1) Mediasi merupakan cara penyelesaian sengketa melalui perundingan 
berdasarkan pendekatan mufakat atau konsensus para pihak.

2) Para pihak meminta bantuan pihak lain yang bersifat tidak memihak yang disebut mediator.

3) Mediator tidak memiliki kewenangan memutus tetapi hanya membantu para pihak yang bersengketa dalam mencari penyelesaian yang dapat diterima oleh para pihak.

Kencenderungan penyelesaian sengketa di luar pengadilan tidak hanya ditemukan pada masyarakat yang sederhana, tetapi pada masyarakat yang modern seperti Amerika Serikat yang menganut penyelesaian sengketa dengan menggunakan pengadilan lebih kuat justru dewasa ini cenderung menyelesaikan sengketanya dengan menggunakan mekanisme di luar pengadilan (Sahnan, 2016: 25). Menurut penulis, penyelesaian sengketa pertanahan melalui jalur mediasi merupakan cara yang tepat dalam mengatasi suatu persoalan di bidang pertanahan. Akan tetapi kelemahan mediasi terdapat pada tidak saling percayanya antara kedua belah pihak yang bersengketa terhadap mediator, sehingga persoalan sengketa tanah di wilayah Madura banyak yang tidak terselesaikan. Namun meskipun demikian upaya tersebut terus dilakukan sampai menemukan jalan keluar dan kedua belah pihak sama-sama merasa puas (saling menerima).

\section{Mekanisme Penyelesaian Sengketa Pertanahan di Wilayah Madura Secara Mediasi Oleh Badan Pertanahan Nasional}

Pada dasarnya, definisi mengenai sengketa pertanahan mendapat sedikit penekanan dalam Peraturan Kepala Badan Pertanahan Nasional Republik Indonesia (BPNRI) Nomor 3 Tahun 2011 tentang Pengelolaan Pengkajian dan Penanganan Kasus Pertanahan, yang menyatakan bahwa sengketa pertanahan adalah perselisihan pertanahan antara orang perseorangan, badan hukum, atau lembaga yang tidak berdampak luas secara sosio-politis. Penyebab timbulnya sengketa pertanahan saat ini dikarenakan ada hal-hal yang belum diperbaiki di antaranya adalah:

1) Kurang tertibnya administrasi pertanahan masa lalu;

2) Ketimpangan struktur penguasaan tanah;

3) Sistem publikasi pendaftaran tanah yang negatif;

4) Meningkatnya kebutuhan tanah, sehingga harga tanah tidak dapat dikendalikan;

5) Peraturan-perundangan saling tumpang tindih;

6) Masih banyak tanah terlantar;

7) Kurang cermat notaris dan pejabat pembuat akta tanah dalam menjalankan tugasnya;

8) Belum terdapat persamaan persepsi para penegak hukum khususnya hakim terhadap peraturan perundang-undangan di bidang pertanahan (Sigit Handoko, 2019: 56). 
Riska Fitriani, menyatakan bahwa upaya Penyelesaian sengketa sengketa pertanahan dilakukan dengan berbagai cara, seperti negosiasi, yaitu dengan proses perundingan atau tawar menawar adanya suatu konsesi dalam permasalahan dan juga ditempuh dengan bantuan pihakpihak yang bisa menfasilitasi tercapainya kesepakatan dengan para pihak yang bersengketa misalnya, Kepala Desa, Kepala Dusun dan Tokoh Agama (Fitriani, 2017: 23).

Pada daerah yang belum berkembang, utamanya di Madura, penyelesaian sengketa tanah pada umumnya dilakukan oleh tokoh-tokoh komunitas yang disegani warga setempat, yaitu Kepala Desa, Kepala Dusun, dan Tokoh Agama. Selain itu, peran tokoh juga membantu untuk menentukan peruntukan serta pengawasan terhadap penggunaan tanah oleh warga setempat (Mudjiono, 2007: 458).

Peraturan Presiden Nomor 10 Tahun 2006 tentang Badan Pertanahan Nasional yang menempatkan mediasi sebagai salah satu tugas pokok dan fungsi (selanjutnya disebut tupoksi) khususnya pada rumusan fungsi pada kedeputian bidang pengkajian dan penanganan sengketa dan konflik pertanahan yaitu melaksanakan alternatif penyelesaian masalah, konflik dan konflik pertanahan, melalui bentuk mediasi, dan fasilitas lainnya, kemudian diperkuat dengan Keputusan Kepala Badan Pertanahan Nasional Nomor 34 Tahun 2007 tentang Petunjuk Teknis Penyelesaian Masalah Pertanahan. Di dalam keputusan tersebut dilampirkan petunjuk teknis Nomor 5/JUKNIS/D.V/2007 tentang Mekanisme Pelaksanaan Mediasi (R. Murad, 2007: 5).

Pasal 1 ayat (1) PERMA Nomor 1 Tahun 2016 dijelaskan bahwa Mediasi adalah cara penyelesaian sengketa melalui proses perundingan untuk memperoleh kesepakatan para pihak dengan dibantu oleh mediator. Mediasi merupakan salah satu alternatif dan cara penyelesaian suatu persengketaan dimana para pihak-pihak yang bersengketa menyerahkan penyelesaiannya kepada seorang mediator dengan maksud untuk memperoleh hasil yang adil dan diterima oleh para pihak yang bersengketa.

Penyelesaian sengketa pertanahan melalui mediasi di lingkungan Badan Pertanahan Nasional sebenarnya bukan hal baru namun sudah dilaksanakan sejak dibentuknya instansi keagrariaan yang kemudian terintegrasi pada tahun 1972 dengan Keputusan Menteri dalam Negeri Nomor 88 Tahun 1972 yang mempersatukan 3 (tiga) unit yang ada pada 3 (tiga) Departemen yaitu:

1) Bagian tata bumi (land use) departemen pertanian;

2) Bagian pendaftaran tanah (kadaster) departemen kehakiman ;

3) Bagian agraria departemen dalam negeri. 
Kepala Seksi Penanganan Masalah dan Pengendalian Pertanahan (PMPP) Kantor Pertanahan Nasional Kabupaten Sampang Sukmono mengatakan bahwa Penyelesaian sengketa pertanahan melalui mediasi yang dilakukan oleh Kantor Pertanahan Nasional merupakan penyelesaian sengketa di luar pengadilan dengan kesadaran dan kesepakatan para pihak yang bersengketa dengan persyaratan yang harus dipenuhi oleh pihak pemohon. Adapun persyaratan yang harus dipenuhi oleh pihak pemohon diantaranya adalah:

1) Surat permohonan mediasi

2) Identitas pemohon

3) Adanya hubungan hukum atau hubungan emosional antara pemohon dengan tanahnya dan didukung dengan data-data yuridis

4) Kesepakatan para pihak (pemohon dan termohon) tanpa adanya paksaan (Sukmono, wawancara, 2018).

Mengenai mekanisme penyelesaian Kasus Pertanahan dalam Peraturan Menteri Agraria dan Tata Ruang/Badan Pertanahan Nasional Nomor 11 Tahun 2016 tentang Penyelesaian Kasus Pertanahan digambarkan seperti tabel dibawah ini:

Tabel 1.1

Penyelesaian Kasus Pertanahan Secara mediasi Menurut Peraturan Menteri Agraria dan Tata Ruang/Badan Pertanahan Nasional Nomor 11 Tahun 2016

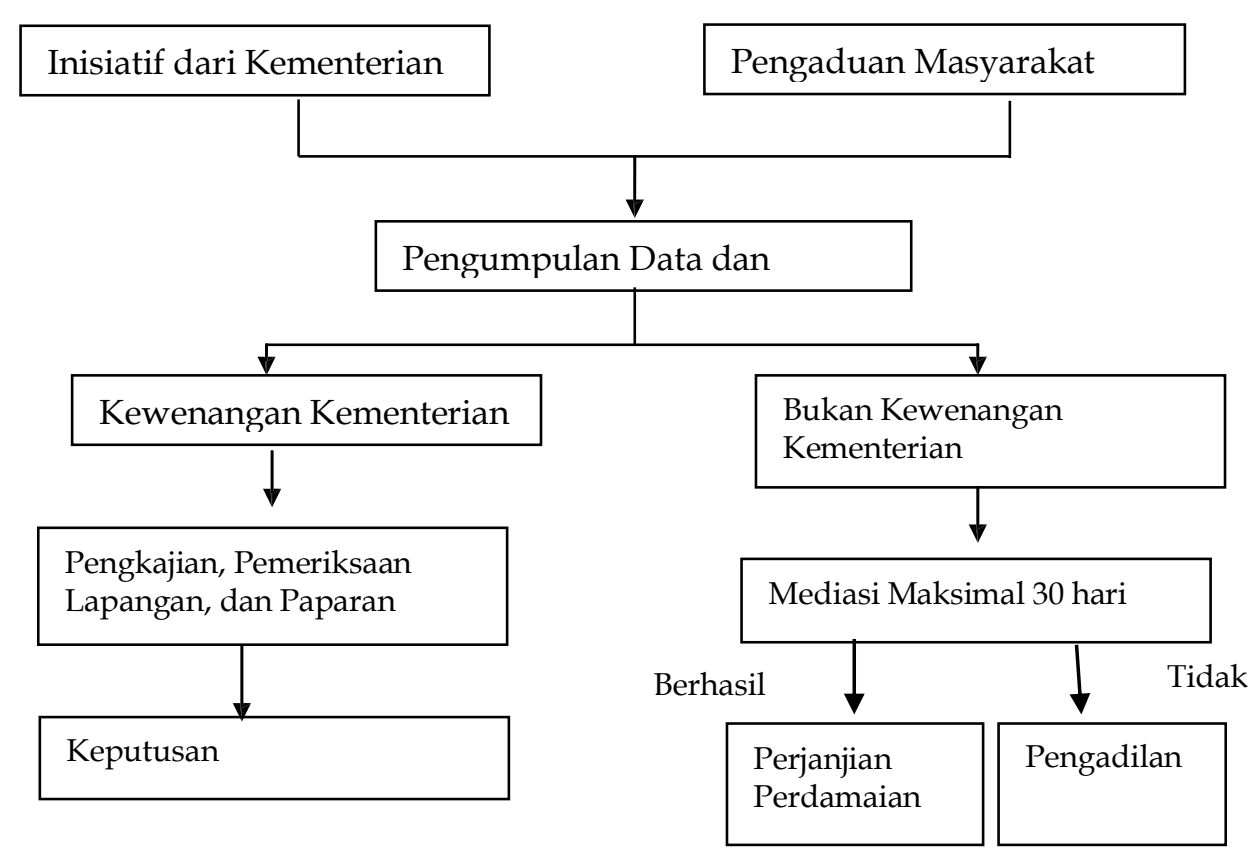


Keterangan:

Pada Pasal 4 huruf a, dan b Peraturan Menteri Agraria dan Tata Ruang/Kepala Badan Pertanahan Nasional Republik Indonesia Nomor 11 Tahun 2016 tentang Penyelesaian Kasus Pertanahan disebutkan bahwa Penyelesaian sengketa dan konflik melalui mediasi dilakukan berdasarkan:

1) Inisiatif dari Kementerian; atau

2) Pengaduan masyarakat.

3) Setelah surat pengaduan dari salah satu pihak yang bersengketa diterima oleh badan pertanahan nasional, selanjutnya dilakukan pengkajian, pemeriksaan lapangan dan paparan. Apabila hasil kajian dan pemeriksaan memenuhi persyaratan, maka mediasi akan dilaksanakan.

4) Setelah dilakukan pengkajian dan pemerikasaan lapangan ternyata ditemukan fakta-fakta yang tidak masuk akal, bukan wewenang badan pertanahan.

5) Apabila mediasi yang dilakukan mediator masih belum menemukan solusi dan para pihak yang bersengketa belum merasa puas, maka pihak mediator masih memberikan jedah waktu 30 (tiga puluh) hari untuk melaksanakan mediasi kembali.

6) Jika mediasi berhasil dilakukan, dibuatlah surat perjanjian perdamaian dan apabila mengalami kegagalan, maka mediator mengarahkan untuk menempuh jalur pengadilan.

Penyelesaian kasus sengketa dan konflik pertanahan dilakukan atas inisiatif kementerian, maka Kementerian melaksanakan pemantauan untuk mengetahui Sengketa dan Konflik yang terjadi dalam suatu wilayah tertentu. Kepala Kantor Pertanahan melaporkan hasil pemantauan kepada Kepala Kantor Wilayah Badan Pertanahan Nasional setiap 4 (empat) bulan sekali dan ditembuskan kepada Menteri. Dalam hal hasil pemantauan perlu ditindaklanjuti, Menteri atau Kepala Kantor Wilayah Badan Pertanahan Nasional memerintahkan Kepala Kantor Pertanahan untuk melakukan kegiatan penyelesaian sengketa dan konflik. Selanjutnya apabila penyelesaian sengketa dan konflik dilaksanakan atas adanya pengaduan masyarakat, maka Kementerian menerima pengaduan terkait sengketa dan konflik dari masyarakat. Pengaduan disampaikan kepada Kepala Kantor Pertanahan secara tertulis, melalui loket pengaduan, kotak surat atau website Kementerian. Pengaduan dibuat sesuai dengan format yang sudah disediakan dalam Peraturan Menteri.

Berdasarkan Pasal 6 Peraturan Menteri Agraria dan Tata Ruang/Badan Pertanahan Nasional Nomor 11 Tahun 2016 tentang Penyelesaian Kasus Pertanahan. Apabila penyelesaian sengketa dan konflik datangnya dari pengaduan masyarakat maka harus memenuhi persyaratan sebagai berikut: 
1) Surat pengaduan, disampaikan kepada Kepala Kantor Pertanahan secara tertulis, melalui loket pengaduan, kotak surat atau website Kementerian.

2) Pengaduan paling sedikit memuat identitas pengadu dan uraian singkat kasus.

3) Pengaduan harus dilampiri dengan fotokopi identitas pengadu, fotokopi identitas penerima kuasa, dan surat kuasa apabila dikuasakan, serta data pendukung atau bukti-bukti yang terkait dengan pengaduan.

4) Pengaduan dibuat sesuai dengan format dari Peraturan Menteri ini.

Format pengaduan yang sudah di tetapkan dalam Peraturan Menteri Agraria dan Tata Ruang/Badan Pertanahan Nasional Nomor 11 Tahun 2016 tentang Penyelesaian Kasus Pertanahan. Pada Pasal 6 ayat (6) Peraturan Menteri Agraria dan Tata Ruang/Badan Pertanahan Nasional Nomor 11 Tahun 2016 tentang Penyelesaian Kasus Pertanahan dinyatakan "Pengaduan sebagaimana dimaksud pada ayat (2) dibuat sesuai dengan format sebagaimana tercantum dalam Lampiran I yang merupakan bagian tidak terpisahkan dari Peraturan Menteri ini". Dalam artian pengaduan tersebut datangnya dari masyarakat.

Pada tipologi sengketa pertanahan yang sudah diselesaikan oleh Kantor Pertanahan Kabupaten Sampang melalui mediasi hanya terdapat 3 (tiga) tipologi sengketa pertanahan, dari 3 (tiga) tipologi sengketa pertanahan seperti tabel dibawah ini:

\section{Tabel 1.2}

Tipologi Sengketa Pertanahan

Kantor Pertanahan Kabupaten Sampang

\begin{tabular}{|l|l|c|c|c|}
\hline No & \multicolumn{1}{|c|}{ Tipologi } & Tahun & $\begin{array}{c}\text { Jumlah } \\
\text { Kasus }\end{array}$ & Prosentase \\
\hline 1 & $\begin{array}{l}\text { Masalahm batas/letak } \\
\text { bidang tanah }\end{array}$ & 2017 & 1 & \\
\hline 2 & $\begin{array}{l}\text { Masalah Penguasaan dan } \\
\text { Pemilikan }\end{array}$ & 2017 & 1 & \\
\hline 3 & Masalah tanah waris & 2018 & 1 & \\
\hline
\end{tabular}

Sumber data Primer Tahun 2018

Menurut Gary Goodpaster menyatakan bahwa mediasi adalah proses negosiasi pemecahan masalah dimana pihak luar yang tidak memihak (impartial) dan netral bekerja dengan pihak yang bersengketa untuk membantu mereka memperoleh kesepakatan atau jalan keluar dengan memuaskan. Mediator tidak mempunyai wewenang untuk memutuskan sengketa antara para pihak. Namun, dalam hal ini para 
pihak memberikan kuasa kepada mediator untuk membantu mereka menyelesaikan permasalahan-permasalahan diantara mereka. Penyelesaian sengketa pertanahan melaui mediasi tidak selamanya memberikan penyelesaian yang memuaskan, meskipun para pihak yang bersengketa telah menyepakati hasil mediasi, salah satu pihak pasti merasa ada yang dirugikan. Walaupun demikian, para pihak tidak akan membawa permasalahan tersebut keranah pengadilan (Litigasi) karena sebelumnya mekanisme mediasi sudah disepakati antara pihak. Mediasi tidak boleh didampingi oleh pengacara atau kuasa hukum karena mediasi lebih mementingkan sifat kekeluargaan dan kesadaran para pihak (Gary Goodpaster, 1993: 201)

Dalam melakukan mediasi sengketa pertanahan, para pihak harus mempunyai fikiran positif terhadap Kantor Pertanahan Kabupaten Sampang selaku mediator, jangan sampai ada niat untuk mempermainkan Kantor Pertanahan Kabupaten Sampang, kadang biasanya termohon ketika mediasi sudah mau dimulai ia sudah punya rasa curiga terhadap mediator sehingga permasalahan tidak dapat diselesaikan dan mediasi menjadi batal. Mediasi merupakan langkah yang tepat dalam menyelesaikan sengketa pertanahan di samping gratis, cepat dan kerahasiannya sangat terjaga (Sukmono, wawancara, 2018).

Berdasarkan Pasal 39 ayat (1) Peraturan Menteri Agraria dan Tata Ruang/Badan Pertanahan Nasional Nomor 11 Tahun 2016 tentang Penyelesaian Kasus Pertanahan disebutkan Peserta Mediasi terdiri dari:

1) Tim Pengolah; Pejabat Kementerian, Kantor Wilayah BPN dan/atau Kantor Pertanahan;

2) Mediator dari Kementerian, Kantor Wilayah BPN dan/atau Kantor Pertanahan;

3) Para pihak dan/atau pihak lain yang terkait; dan/atau

Pakar dan/atau ahli yang terkait dengan Sengketa dan Konflik, Instansi terkait, dan unsur masyarakat, tokoh masyarakat/adat/agama, atau pemerhati/pegiat agraria dan penataan ruang, serta unsur-unsur lain, apabila diperlukan.

Mediasi hanya dapat dilakukan satu kali melalui kesepakatan para pihak yang bersengketa tanpa adanya biaya. Dalam Pasal 39 ayat (3) dan (4) Peraturan Menteri Agraria dan Tata Ruang/Badan Pertanahan Nasional Nomor 11 Tahun 2016 tentang Penyelesaian Kasus Pertanahan dinyatakan Dalam hal Mediasi tidak dapat dihadiri oleh salah satu pihak yang berselisih, maka pelaksanaannya dapat ditunda agar semua pihak yang berselisih dapat hadir. Selanjutnya, apabila setelah diundang 3 (tiga) kali secara patut pihak yang berselisih tidak hadir dalam Mediasi, maka Mediasi batal dan para pihak dipersilahkan menyelesaikan sengketa atau konflik sesuai dengan ketentuan peraturan perundang-undangan. Waktu 
maksimal pelaksanaan mediasi paling lama 30 (tiga puluh) hari (Sukmono,wawancara, 2018).

Kantor Pertanahan mempunyai kewenangan untuk menyelesaikan kasus sengketa pertanahan melalui mediasi seperti yang sudah dinyatakan dalam Pasal 37 ayat (1) Peraturan Menteri Agraria dan Tata Ruang/Kepala Badan Pertanahan Nasional Republik Indonesia Nomor 11 Tahun 2016 tentang Penyelesaian Kasus Pertanahan bahwa Penyelesaian sengketa atau konflik dapat dilakukan melalui mediasi, namun Kantor Pertanahan belum bisa sepenuhnya melakukan amanat peraturan tersebut, hal ini disebabkan Kantor Pertanahan belum mempunyai mediator khusus untuk menangani penyelesaian kasus sengketa pertanahan. Mediator seharusnya mempunyai kualifikasi khusus untuk menangani masalah. Selama ini setiap kasus sengketa pertanahan hanya ditangani oleh Kasi atau Kasubsi penanganan masalah atau sengketa (Saifuddin, 2018: 12).

Kasi penanganan masalah sengketa, konflik dan perkara pertanahan Kantor Pertanahan Kabupaten Bangkalan Saifuddin menjelaskan bahwa Semua kasus sengketa pertanahan sudah layak ditangani Badan Pertanahan Nasional supaya dapat memberikan WinWin solution terhadap setiap permasalahan antar pihak yang bersengketa dengan memperhatikan cara keseimbangan (Equity Theory) yaitu cara yang lebih memperhatikan norma-norma dan prinsip keadilan. (Saifuddin, wawancara, 2018).

Pada tipologi sengketa pertanahan yang sudah diselesaikan oleh Kantor Pertanahan Kabupaten Bangkalan melalui mediasi tipologi sengketa pertanahan, seperti tabel di bawah ini:

Tabel 1.3

Tipologi Sengketa Pertanahan

Kantor Pertanahan Kabupaten Bangkalan

\begin{tabular}{|l|l|c|c|c|}
\hline No & \multicolumn{1}{|c|}{ Tipologi } & Tahun & $\begin{array}{l}\text { Jumlah } \\
\text { Kasus }\end{array}$ & Prosentase \\
\hline 1 & $\begin{array}{l}\text { Masalah batas/letak } \\
\text { bidang tanah }\end{array}$ & 2017 & 1 & \\
\hline
\end{tabular}

Sumber data Primer Tahun 2017

Kasus sengketa pertanahan di Kabupaten Bangkalan yang paling menonjol adalah kasus sengketa tentang batas (tata Letak) meskipun ada juga sebagian kasus sengketa tanah waris, jual beli yang rumit namun mengenai kasus tersebut tidak sampai dimediasi karena sudah diselesaikan secara kekeluargaan. Adapun persyaratan yang harus terpenuhi untuk bisa dilakukan mediasi di Kantor Pertanahan Kabupaten 
Bangkalan d iantaranya adalah adanya surat permohonan dari pihak terkait, uraian pokok masalah yang mau dimediasi harus jelas, adanya pikiran positif,dan kemauan pihak yang bersengketa.

Setelah persyaratan yang sudah terpenuhi oleh para pihak untuk dilakukan mediasi, bukan berarti mediasi akan cepat terlaksana, namun masih ada kendala-kendala yang harus dihadapi oleh Kantor Pertanahan Kabupaten Bangkalan, hal ini dijelaskan oleh Saifuddin karena sifat dan pikiran manusia selalu berubah-ubah. Adapun kendala yang dapat menggagalkan mediasi yaitu salah satu pihak merasa benar, merasa tidak cocok atau dianaktirikan, waktunya tidak tepat untuk dilakukan mediasi.

Kendala-kendala yang disebut diatas bisa menggagalkan mediasi, namun pihak Kantor Pertanahan Kabupaten Bangkalan terus berupaya bagaimana mediasi ini tetap dijalankan, dengan cara Kasi penanganan masalah atau sengketa melakukan pendekatan kepada Kepala Desa setempat dengan menanyakan pokok permasalahan sengketa, juga melakukan pendekatan terhadap tokoh masyarakat (Tomas) dengan upaya tersebut kemudian dilakukan pemanggilan kembali kepada salah satu pihak. Jika upaya pemanggilan sudah tidak dihiraukan sampai 3 (tiga) kali panggilan maka penyelesaian sengketa melalui mediasi dianggap gagal. (Saifuddin, wawancara, 2018: 12)

Sebelum mediasi dimulai dan para pihak yang diundang sudah hadir, maka mediator memanggil pihak pemohon untuk memberikan penjelasan terkait permasalahan yang dihadapi, selanjutnya pihak termohon dipanggil untuk ditanya kesiapannya. Mediator menjelaskan terhadap para pihak yang bersengketa bahwa mediasi itu sifatnya terbuka untuk mencari solusi terhadap permasalahan yang dihadapi. Mediasi harus sama-sama saling menghargai dan mendengarkan pendapat orang lain bukan berdasarkan pendapat sendiri. Kemudian setelah para pihak diberikan penjelasan, maka dibuatlah kesepakan mengenai batasan waktu mediasi karena kalau tidak dibatasi akan terjadi debat kusir antara pihak yang bersengketa.

Waktu mediasi tergantung keadaan, bisa 2 (dua) atau 3 (tiga) jam tergantung permasalahan yang akan dimediasi. Misalnya, permasalahan yang dimediasi tidak rumit, maka waktu dua (2) jam sudah cukup, kalau sekiranya masalahnya rumit dan belum bisa selesai pada hari itu maka waktu yang diberikan mediator hanya satu jam setengah dan mediasi akan dilanjutkan kemudian hari. Biasanya, waktu mediasi selanjutnya disepakati para pihak yang bersengketa. Akan tetapi di Kantor Pertanahan Kabupaten Bangkalan jedah waktu yang diberikan satu minggu. Pada waktu mediasi dilaksanakan semua pembicaraan dari para pihak yang hadir dicatat oleh notulen. Apabila mediasi pada hari itu sudah menemukan solusi bagi para pihak yang bersengketa, maka 
kesepakatan para pihak dibuatkan berita acara mediasi (Saifuddin, wawancara, 2018).

Menurut Saifuddin, kekuatan hukum berita acara mediasi sama seperti putusan pengadilan, legalitasnya diakui karena para pihak yang bersengketa sama-sama membubuhkan tanda tangan dan dalam berita acara mengetahui Kantor Pertanahan Kabupaten Bangkalan. Meskipun demikian kadang para pihak belum merasa puas atau masih ragu dengan berita acara yang sudah disepakati dan masih menimbulkan pertanyaan maka, pihak Kantor Pertanahan Kabupaten Bangkalan menganjurkan kepada pihak yang bersengketa untuk diberitahukan ke pengadilan bahwa kami sudah menyelesaikan sengketa melalui mediasi. Selama ini, sengketa pertanahan di Kabupaten Bangkalan yang sudah diselesaikan di Kantor Pertanahan Kabupaten Bangkalan tidak pernah dibawa ke ranah pengadilan karena para pihak sudah berjanji tidak akan melanggar kesepakatan.

Sementara di Kantor Pertanahan Kabupaten Pamekasan, tipologi sengketa pertanahan yang sudah diselesaikan melalui mediasi hanya kasus sengketa hak (yuridis) dan Batas (tata letak tanah), sedangkan untuk kasus sengketa tanah waris Kantor Pertanahan Kabupaten Pamekasan belum menerima pengaduan dari para pihak. (Moh. Fadli, wawancara, 2018)

Tabel 1.4

Tipologi Sengketa Pertanahan

Kantor Pertanahan Kabupaten Pamekasan

\begin{tabular}{|c|c|c|c|c|}
\hline No & Tipologi & Tahun & $\begin{array}{l}\text { Jumlah } \\
\text { Kasus }\end{array}$ & Prosentase \\
\hline 1 & $\begin{array}{l}\text { Masalah batas/letak } \\
\text { bidang tanah }\end{array}$ & 2018 & 1 & \\
\hline 2 & $\begin{array}{l}\text { Masalah Penguasaan } \\
\text { dan Pemilikan }\end{array}$ & 2018 & 1 & \\
\hline 3 & Masalah tanah waris & & & \\
\hline
\end{tabular}

Sumber data Primer Tahun 2018

Penyelesaian sengketa pertanahan melalui mediasi di Kantor Pertanahan Kabupaten Pamekasan bukan hal yang mudah untuk dilaksanakan, meskipun Peraturan Menteri Agraria dan Tata Ruang/Badan Pertanahan Nasional Nomor 11 Tahun 2016 tentang Penyelesaian Kasus Pertanahan sudah memerintahkan kepada kantor pertanahan untuk menyelesaikan kasus sengketa dan konflik pertanahan melalui mediasi sebagaimana yang sudah disebutkan dalam Pasal 37 ayat (1) Peraturan Menteri Agraria dan Tata Ruang/Badan Pertanahan 
Nasional Nomor 11 Tahun 2016 tentang Penyelesaian Kasus Pertanahan bahwa Penyelesaian Sengketa atau Konflik sebagaimana dimaksud dalam Pasal 12 ayat (5) dapat dilakukan melalui Mediasi. Akan tetapi mengenai mekanisme penyelesaiannya diserahkan kepada Kantor Pertanahan Kabupaten masing-masing, karena setiap Kabupaten mempunyai ciri khas yang berbeda, baik itu dari segi kehidupan masyarakatnya atau mekanisme penyelesaian sengketanya. (Moh. Fadli, Wawancara, 2018).

Sementara ini, Kantor Pertanahan Kabupaten Sumenep hanya dapat menyelesaikan satu (1) kali kasus sengketa tanah hak milik punya yayasan atas Nama Sumono dengan Ibu Dwi Oktavia selaku pemohon melalui mediasi. Kasus tersebut sebenarnya sudah lama dan pada akhirnya bisa diselesaikan di Kantor Pertanahan Kabupaten Sumenep melalui mediasi dengan dibuatkan berita acara kesepakatan mediasi. Pada waktu mau melaksanakan mediasi di Kantor Pertanahan Kabupaten Sumenep, terhadap para pihak waktu yang diberikan antara 3 (tiga) sampai 4 (empat) jam, tetapi kadang mediasi bisa selesai waktu itu, dan ada juga yang masih ditunda, kemudian akan dilanjutkan hari berikutnya sesuai kesepakan para pihak.

Kantor Pertanahan Kabupaten Sumenep dalam melakukan mediasi, hukumnya tidak wajib apalagi memaksa para pihak untuk melakukan mediasi di Kantor Pertanahan. Mediasi bisa dilaksanakan bukan hanya oleh Kantor Pertanahan, akan tetapi Kepala Desa juga mempunyai kewajiban dalam menyelesaikan perselisihan di desanya yang bisa dilakukan di Kantor Desa atau Balai Desa setempat. Apabila Kepala Desa tidak mampu menyelesaikannya, maka membuat surat permohonan kepada Kantor Pertanahan untuk menjadi Mediator. (Ismail, wawancara, 2018).

Menurut Dodi, selaku seksi pendaftaran tanah di Kantor Pertanahan Kabupaten Sumenep, hadirnya Kepala Desa dalam kasus penyelesaian tanah, hukumnya wajib karena Kepala Desa kadang ikut serta dalam menentukan kebijakan tanah sengketa di Desa. Hal ini sesuai dengan Pasal 26 ayat (4) huruf k Undang-Undang Nomor 6 Tahun 2014 tentang Desa disebutkan mengenai salah satu kewajiban Kepala Desa yaitu untuk menyelesaikan perselisihan masyarakat di Desa. Pemerintahan Desa merupakan bagian dari struktur hukum yang diharapkan dapat menyelesaikan sengketa yang bersifat kekeluargaan, seperti sengketa tanah. Akan tetapi, kadang Kepala Desa berpihak kepada salah satu orang yang bersengketa (Dodi, wawancara, 2018).

Berdasarkan penelitian yang dilakukan di Kantor Pertanahan, dari 4 (empat) Kabupaten yang ada di Madura yakni, Sampang, Bangkalan, Pamekasan dan Sumenep pada penyelesaian sengketa pertanahan secara mediasi. Masing-masing Kabupaten mengandung kelebihan dan 
kekurangan masing-masing, karena mekanisme penyelesaian yang dipergunakan berbeda-beda. Proses mediasi dalam rangka penyelesaian sengketa pertanahan yang mempunyai tujuan memberikan kepastian hukum dan keadilan mengenai penguasaan, pemilikan, penggunaan dan pemanfaatan tanah.

\section{Cara Mediator Dalam Menyelesaikan Sengketa Pertanahan Di Wilayah Madura Secara Mediasi Oleh Badan Pertanahan Nasional}

Peraturan Dasar Pokok-Pokok Agraria (selanjutnya disebut UUPA). Di dalam Pasal 2 ayat (2) Undang-Undang Nomor 5 Tahun 1960 tentang Peraturan Dasar Pokok-Pokok Agraria dinyatakan bahwa "Hak menguasai dari negara termaksud dalam ayat (1) Pasal ini memberi wewenang untuk":

1) Mengatur dan menyelenggarakan peruntukan, penggunaan, persediaan dan pemeliharaan bumi, air dan ruang angkasa tersebut;

2) Menentukan dan mengatur hubungan-hubungan hukum antara orang-orang dengan bumi, air dan ruang angkasa;

3) Menentukan dan mengatur hubungan-hubungan hukum antara orang-orang dan perbuatan-perbuatan hukum yang mengenai bumi, air dan ruang angkasa.

Penyelesaian sengketa melalui mediasi di Kantor Pertanahan Nasional merupakan penyelesaian sengketa di luar peradilan (Non litigasi) sebagaimana telah diatur dalam Pasal 1 angka 10 UndangUndang Nomor 30 Tahun 1999 tentang Arbitrase dan Alternatif Penyelesaian Sengketa yang menyatakan bahwa Salah satu alternatif penyelesaian sengketa diselesaikan melalui proses mediasi yang merupakan proses penyelesaian berdasarkan prinsip win-win solution yang diharapkan memberikan penyelesaian secara memuaskan dan diterima semua pihak.

Mediasi merupakan rumusan sebagai salah satu proses alternatife penyelesaian masalah dengan bantuan pihak ketiga (mediator) dan prosedur yang disepakati oleh para pihak dimana mediator memfasilitasi untuk dapat tercapai suatu kesepakatan (perdamaian) yang saling menguntungkan para pihak. Secara singkat, mediasi dalam pembahasan penelitian ini dapat disebut sebagai Mediasi Pertanahan. Mediator adalah orang atau pejabat yang ditunjuk dari jajaran Kantor Pertanahan yang disepakati oleh para pihak yang bersengketa dan diberi surat tugas untuk menyelesaikan suatu permasalahan. Kewenangan mediator dalam menyelesaikan sengketa pertanahan adalah menentukan keberhasilan dan efektifitas proses penyelesaian sengketa dan harus layak memenuhi kualifikasi atau 
penilaian tertentu dengan kemampuan negosiasi dan komunikasi (Arnowo, 2017: 307)

Proses penyelesaian sengketa antara para pihak yang dilakukan dengan bantuan pihak ketiga (mediator) yang netral dan tidak memihak kepada salah satu pihak hanya sebagai fasilitator, dan hasil untuk mencapai suatu kesepakatan tetap diambil oleh para pihak itu sendiri (I Made Widnyana, 2009: 111).

Badan Pertanahan Negara pada dasarnya bukan lembaga penyelesaian sengketa, maka hasil mediasi yang dituangkan dalam Perjanjian Perdamaian tidak mempunyai kekuatan hukum mengikat, sehingga ada kekhawatiran jika terjadi pengingkaran oleh salah satu pihak terhadap kesepakatan yang dituangkan dalam Perjanjian Perdamaian, permasalahan tidak selesai. Untuk memperoleh kekuatan hukum mengikat dan memperoleh upaya paksa untuk dilaksanakan, kesepakatan perdamaian tersebut diajukan ke Pengadilan untuk memperoleh Akta Perdamaian dengan cara mengajukan gugatan. Menurut Pasal 1 angka 8 PERMA Nomor 1 Tahun 2016 akta perdamaian adalah "kesepakatan hasil Mediasi dalam bentuk dokumen yang memuat ketentuan penyelesaian sengketa yang ditandatangani oleh Para Pihak dan Mediator"(Kurniati \& Fakhriah, 2017: 95-105).

Sukmono, menyatakan bahwa Mediator selaku pelaksana kewenangan dan sebagai pihak ketiga dalam menyelesaikan sengketa tanah hanya sebagai fasilitator dan penengah yang bersifat netral tidak memihak kepada siapapun, karena para pihak sebelum dilakukan mediasi sudah dipanggil dan dinegosiasi terkait persolaan yang akan dimediasi. Mediator hanya membantu mencarikan solusi secara sukarela tanpa adanya paksaan dan tekanan dari para pihak (Sukmono, Wawancara, 2018).

Mediator tidak mempunyai kewenangan apapun apalagi memberikan putusan terhadap jalannya mediasi supaya para pihak mempunyai pikiran positif. Mediator sebagai pejabat yang berwenang (authoritative mediator) harus mempunyai pengetahuan dan pengalaman yang luas dengan sengketa yang ditangani. Walaupun mediator di Kantor Pertanahan tidak memiliki sertifikat mediator, akan tetapi mengenai penanganan masalah kasus sengketa tanah melalui mediasi dipasrahkan sepenuhnya oleh Kepala Kantor Pertanahan Kabupaten Sampang kepada seksi penanganan masalah pertanahan (Sukmono, wawancara, 2018).

Ketentuan Pasal 1 angka 8 Peraturan Menteri Agraria dan Tata Ruang/Badan Pertanahan Nasional Nomor 11 Tahun 2016 tentang Penyelesaian Kasus Pertanahan Mediator adalah pihak yang membantu para pihak dalam proses perundingan guna mencari berbagai kemungkinan penyelesaian sengketa atau konflik tanpa menggunakan 
cara memutus atau memaksakan sebuah penyelesaian. Dalam hukum administrasi negara mediator merupakan pejabat pemerintah yang berasal dari Kementerian Kantor Wilayah Badan Pertanahan Nasional atau Kantor Pertanahan mempunyai kewenangan untuk menyelesaikan kasus sengketa pertanahan sebagaimana Pasal 11 ayat (3) Peraturan Menteri Agraria dan Tata Ruang/ Kepala Badan Pertanahan Nasional Republik Indonesia Nomor 11 Tahun 2016 tentang Penyelesaian Kasus Pertanahan meliputi:

a) Kesalahan prosedur dalam proses pengukuran, pemetaan dan/atau perhitungan luas;

b) Kesalahan prosedur dalam proses pendaftaran penegasan dan/atau pengakuan hak atas tanah bekas milik adat;

c) Kesalahan prosedur dalam proses penetapan dan/atau pendaftaran hak tanah;

d) Kesalahan prosedur dalam proses penetapan tanah terlantar;

e) Tumpang tindih hak atau sertifikat hak atas tanah yang salah satu alas haknya jelas terdapat kesalahan;

f) Kesalahan prosedur dalam proses pemeliharaan data pendaftaran tanah;

g) Kesalahan prosedur dalam proses penerbitan sertifikat pengganti;

h) Kesalahan dalam memberikan informasi data pertanahan;

i) Kesalahan prosedur dalam proses pemberian izin;

j) Penyalahgunaan pemanfaatan ruang; atau

k) Kesalahan lain dalam penerapan peraturan perundang-undangan.

Sikap mediator selaku pihak ketiga pada waktu mediasi dimulai harus duduk di tengah tanpa ada beban, kemudian menjelaskan kepada para pihak kalau kami netral dan tidak memihak terhadap siapapun. Selanjutnya, terhadap para pihak memberikan pemahaman bahwa dalam menyelesaikan kasus sengketa sikap kami memandang dan berpedoman pada peraturan perundang-undangan yang ada. Setiap kegiatan mediasi dituangkan dalam berita acara mediasi. Kesepakatan secara tertulis dengan menggunakan format perjanjian mempunyai kekuatan hukum mengikat.

Mediasi pertanahan sebagaimana tersebut di atas tidak melibatkan kuasa hukum seperti pengadilan sebagaimana yang ditentukan dalam Undang-Undang Nomor 30 Tahun 1999. Jika terdapat penyimpangan, mediator harus mengingatkan untuk kembali pada fokus permasalahan. Pelaksanaan kewenangan mediator dalam hal ini adalah Kantor Pertanahan yang diperoleh secara atribusi merupakan kewenangan yang berasal langsung dari peraturan perundang-undangan. Dengan kata lain, organ pemerintahan yang memperoleh kewenangan secara langsung dari peraturan perundang-undangan (Philipus M. Hadjon, 1994: 8). 


\section{SIMPULAN}

Berdasarkan kajian pembahasan di atas, maka dapat disimpulkan bahwa mekanisme penyelesaian sengketa pertanahan di wilayah Madura secara mediasi oleh Badan Pertanahan Nasional yakni, Sampang, Bangkalan, Pamekasan dan Sumenep merupakan penyelesaian kasus sengketa tanah dalam ranah keperdataan. Adapun mekanisme penyelesaian, yaitu pertama menerima surat pengaduan dari salah satu pihak, kedua Menelaah surat pengaduan, ketiga Memanggil Camat, Kepala Desa, Perangkat Desa, dan Tokoh Masyarakat untuk dimintai keterangannya mengenai sengketa pertanahan. Hal ini sesuai ketentuan Pasal 6 ayat (6) dan Pasal 41 ayat (2)Peraturan Menteri Agraria dan Tata Ruang/Kepala Badan Pertanahan Nasional Republik Indonesia Nomor 11 Tahun 2016 tentang Penyelesaian Kasus Pertanahan.

Mediator dalam menyelesaikan kasus pertanahan secara mediasi dengan cara, Pertama Memanggil kedua belah pihak yang bersengketa, kedua Upaya mediasi dilakukan terhadap kedua belah pihak yang bersengketa, ketiga Apabila mediasi berhasil maka dibuatlah berita acara mediasi dan surat perjanjian perdamaian dan apabila tidak berhasil maka mediator mengarahkan untuk menyelesaikan di lewat jalur litigasi.

\section{DAFTAR PUSTAKA}

\section{Buku-buku}

Candra Irawan, (2010). Aspek Hukum dan Mekanisme Penyelesaian Sengketa di luar pengadilan (Alternative Dispute Resolution) di Indonesia, Bandung: Mandar Maju.

I Made Widnyana, (2009). Alternatif Penyelesaian Sengketa (ADR), Jakarta: PT. Fikahati Aneska.

Maria S.W Sumardjono, (2008). Tanah Dalam Perspektif Hak Ekonomi Sosial Dan Budaya, Jakarta: Kompas Media Nusantara.

Nurus Zaman, (2016). Politik Hukum Pengadaan Tanah Antara Kepentingan Umum dan Perlindungan Hak Asasi Manusia, Bandung: Refika Aditama.

Mukti Fajar \& Yulianto Achmad, 2010, Dualisme Penelitian Hukum Normatif $\mathcal{E}$ Empiris, Yogyakarta, Pustaka Pelajar

Soerjono Soekanto, (2014). Pengantar Penelitian Hukum, Jakarta: Universitas Indonesia Press.

Ridwan HR, (2016). Hukum Administrasi Negara, Jakarta: RajaGrafindo persada.

Waskito, Hadi Arnowo, (2017). Pertanahan, Agraria, dan Tata Ruang, Jakarta: Balebat Dedikasi Prima. 


\section{Jurnal-Jurnal}

Herlina Ratna Sambawa Ningrum, Analisis Hukum Sistem Penyelesaian Sengketa Atas Tanah Berbasis Keadilan, Jurnal Pembaharuan Hukum Volume I No. 2 Mei-Agustus 2014

Juwita Tarochi Boboy, Budi Santoso, Irawati, Penyelesaian Sengketa Pertanahan Melalui Mediasi Berdasarkan Teori Dean G.Pruitt Dan Jeffrey Z.Rubin, Notarius, Volume 13 No. 2 (2020) Program Studi Magister Kenotariatan Fakultas Hukum, Universitas Diponegoro

Mudjiono, Alternatif Penyelesaian Sengketa Pertanahan Di Indonesia Melalui Revitalisasi Fungsi Badan Peradilan, Jurnal Hukum, No. 3 Vol.14 Juli 2007

Nanda Yusri Pratama, (2016) Penyelesaian Sengketa Dengan Mediasi Melalui Badan Pertanahan Nasional Antara PT. Meridan Sejati Surya Plantation Dengan Kelompok Tani Tunas Jaya di Kabupaten Siak Provinsi Riau, JOM Fakultas Hukum Vol. III No. 2 Oktober 2016

Nuraini Aisiyah, Bambang Suyudi, I Gusti Nyoman Guntur, Wisnuntoyo, (2015) Sengketa Pemilikan Tanah Antara TNI dan Warga Masyarakat di Urut Sewu Kebumen, Jurnal Agraria dan Pertanahan, Volume 1, No. 2, November 2015

Nia Kurniati, Efa Laela Fakhriah, BPN Sebagai Mediator Dalam Penyelesaian Sengketa Tanah Di Indonesia Pasca Perkaban No. 11 Tahun 2016, Sosiohumaniora, Volume 19, No. 2 Juli 2017, Fakultas Hukum Universitas Padjadjaran

Ria Andanari, Sigit Handoko, Penyelesaian Sengketa Tanah Melalui Mediasi Di Kantor Pertanahan Kabupaten Kulon Progo, Jurnal Kewarganegaraan Vol. 3 No. 1 Juni 2019, Universitas Pgri Yogyakarta

Riska Fitriani, Penyelesaian Sengketa Lahan Hutan Melalui Proses Mediasi Di Kabupaten Siak, Jurnal Ilmu Hukum, Volume 3 No. 1

Sahnan, Pilihan Hukum Penyelesaian Sengketa Tanah Di Luar Pengadilan (Studi Kasus Tanah Rowok, Lombok Tengah, NTB), Mimbar Hukum, Volume 27, Nomor 3, Oktober 2015

\section{Peraturan Perundang-Undangan}

Undang-Undang Dasar Negara Republik Indonesia Tahun 1945

Undang-Undang Pokok Agraria Nomor 5 Tahun 1960

Peraturan Presiden Republik Indonesia Nomor 20 Tahun 2015 tentang Badan Pertanahan Nasional

Keputusan Kepala Badan Pertanahan Nasional Republik Indonesia Nomor 34 Tahun 2007 tentang Petunjuk Teknis Penanganan dan Penyelesaian Masalah Pertanahan 
Keppres Nomor 34 Tahun 2003, tentang Kebijakan Nasional dibidang Pertanahan

Peraturan Menteri Agraria dan Tata Ruang/ Kepala Badan Pertanahan Nasional Republik Indonesia Nomor 11 Tahun 2016 tentang Penyelesaian Kasus Pertanahan 